\title{
Determination of larval melanization in the moth, Mamestra brassicae, and the role of melanin in thermoregulation
}

\author{
DAVID GOULSON \\ Ecology and Biocontrol, NERC Institute of Virology and Environmental Microbiology, Mansfield Rd, Oxford OX1 3SR, \\ U.K.
}

\begin{abstract}
Variability in the colour of lepidopteran larvae has been recorded in a broad range of species, yet little is known of its evolutionary significance, or whether it has a genetic basis. I assess the role of genes and environment in determining the degree of larval melanization in the moth, Mamestra brassicae, and examine functional aspects of larval pigmentation. In particular, whether melanization is of importance in thermoregulation, and whether larvae differing in melanization exhibit concurrent differences in size, rate of development, and fecundity. In the fourth and fifth instars, larval M. brassicae exhibit a continuous range of colour from pale green to black: a classification scheme is described to quantify this variation. Heritability $\left(h^{2}\right)$ was measured using regression of brood means against mid-parent values for 36 broods (2339 offspring), and was estimated to be $0.237 \pm 0.07$ (SD) for fourth instar larvae and $0.421 \pm 0.10$ (SD) for fifth instar larvae. However, environmental factors mediated development of larval colour: larvae were darker when reared at low temperature $\left(12^{\circ} \mathrm{C}\right)$ compared to high $\left(24^{\circ} \mathrm{C}\right)$. Direct measurement of larval temperatures using thermocouples inserted into the alimentary canal indicated that dark larvae absorbed more radiant heat, and thus under illumination consistently maintained a higher body temperature than pale larvae. Hence dark larvae are presumed to be at a selective advantage at low ambient temperatures, and increased melanization of larvae reared at low temperatures may be adaptive. I suggest that variation within natural populations may be maintained by fluctuating weather conditions. Dark larvae were found to be smaller, but developed more quickly than light larvae so that weight at pupation, time to pupation, and fecundity (measured by the number of fertile eggs produced) did not differ according to colour. Further studies are suggested to examine the influence of larval colour on thermoregulation, growth rates and predation in the field.
\end{abstract}

Keywords: larval colour, Lepidoptera, melanin, polymorphism, thermoregulation, variation.

\section{Introduction}

Studies on morphological variation provide the cornerstones of classical ecological genetics, particularly those on Biston betularia (Kettlewell, 1973), Maniola jurtina (Dowdeswell, 1981; Brakefield, 1984), Panaxia dominula (Jones, 1989) and Cepaea (Jones et al., 1977) which attempted to determine the relative roles of selection and neutrality in maintaining natural variation. All of these studies concentrated on variability in colour and pattern, which are both easily recorded without use of expensive equipment, and likely to have a direct bearing on fitness of the individual via apparency to predators, apparency to conspecifics, or thermoregulation. The preponderance of studies on adult Lepidoptera is probably a reflection of the interests of early entomologists, and the ease with which they can be preserved as specimens. The immature stages of Lepidoptera are in many species more variable in colour than the adults; for example, polymorphisms have been described in eggs (Wickman \& Karlsson, 1987) and pupae (Smith et al., 1988). However, variability in colour, often described as phase polymorphism (Kazimirova, 1992), has most frequently been described in larvae (Faure, 1943a, b; Matthée, 1947; Long, 1953; Iwao, 1962; Drooz, 1966; Sasakawa \& Yamazaki, 1967; Hodjat, 1970; Kettlewell, 1973; Hintze-Podufal, 1974; Johnson et al., 1985; Fescemyer \& Hammond, 1986; Tojo, 1991). It has long been known that, in some species, the frequency of dark phase larvae can be increased by rearing at high densities, prompting comparison with solitary and 
gregarious phases in locusts (Faure, 1943 a,b; Matthée, 1945). The induction of a dark phase by high densities is now known to be a widespread phenomenon amongst the Lepidoptera, including five species in the genus Spodoptera (Faure, 1943 a, b; Matthée, 1947; Hodjat, 1970; Tojo, 1991), three Orthosia species, Autographa gamma and Lacanobia oleracea (Long, 1953), and Agrotis ipsilon (Sappington et al., 1992), (all Noctuidae) Pavonia pavonia (Saturnidae) (Long, 1953) and Cephonodes hylas (Sphingidae) (Sasakawa \& Yamazaki, 1967). Kunimi \& Yamada (1990) found both an increase in melanization and a concurrent increase in resistance to viral disease at high rearing densities in Mythimna separata (Noctuidae).

Mamestra brassicae (Noctuidae: Hadeninae) (L.) is a widespread and generally abundant moth throughout the Eurasiatic region, in Britain becoming less common in the north. The larvae are polyphagous, with a preference for Brassica crops, and remain on the foodplant and feed by day and night. In the early instars larvae feed exclusively on the lower surface of leaves, but by the fourth instar can be found on both upper and lower surfaces (pers. obs.). Larvae exhibit variation in their degree of melanization, particularly during the fifth instar, ranging from pale green to dark brown/black (Hirata, 1954; Burov \& Mokrousova, 1970). The frequency of darker phenotypes increases at higher rearing densities (Hirata, 1957 a, b, 1962; Saulich, 1975; Kazimirova, 1992).

This study examines the evolutionary significance of variation in larval melanization, by attempting to quantify genetic and environmental components, and by measuring aspects of the selective value of melanin. I describe and quantify melanization in a captive population, and measure the narrow-sense heritability $\left(h^{2}\right)$ using regression of brood means against midparent values (Falconer, 1981). I also examine how melanization is mediated by the environment, by rearing larvae under a range of controlled regimes with manipulation of temperature, humidity, lighting, and larval density. Melanization is likely to affect larval thermoregulation, for colour affects absorption of radiated heat (Watt, 1968; Dennis \& Shreeve, 1989), and larvae may rely on absorption of solar radiation to remain active when ambient temperatures are low (Porter, 1983). I assess whether melanization influences body temperature by direct measurement of larval internal temperatures while varying ambient temperature and lighting intensity. I also test whether the degree of melanization is related to larval size and rate of development, for the thermoregulatory abilities of a larva will have a direct bearing on its metabolic rate (Shibazaki \& Ito, 1969).

\section{Materials and methods}

Insect material for this study was obtained from female moths trapped at light near Winchester, Hampshire in 1991 , and the offspring were reared continuously in captivity on artificial diet (Hunter et al., 1984). Comparison of larvae on artificial diet with those found in the wild suggested that larvae exhibited the same degree of colour variation on both foods, and use of artificial diet greatly facilitates the maintenance of constant environmental conditions when rearing larvae.

\section{Genetic components of variation in melanization}

One hundred and twenty larvae were reared individually at $24^{\circ} \mathrm{C}$ in the dark, and their degree of melanization recorded on a scale of one to four from light to dark (see results), when in both the fourth and fifth instars. On hatching, the resulting adults were randomly paired in cylindrical plastic containers $(10$ $\mathrm{cm}$ diameter $\times 6.5 \mathrm{~cm}$ high) lined with tissue paper. Each pair was provided with a pad of tissue soaked in 10 per cent honey solution which was renewed every two days. Containers were stored at $24^{\circ} \mathrm{C}$ with $18: 6 \mathrm{~h}$ L:D, under which conditions most pairs mated and produced fertile eggs. The $F_{1}$ generation were then reared individually under the same environmental conditions as their parents, and melanization scored as fourth and fifth instars. Offspring in excess of 100 for each brood were discarded. In total 2,339 larvae were reared from 36 broods.

\section{Environmental effects on melanization}

Four environmental variables were chosen, on the basis of ease of manipulation and reported associations with larval colour: temperature, humidity, light regime and rearing density. Larvae were reared from first to fifth instar in clear plastic pots $(10 \mathrm{~cm}$ diameter $\times 6.5 \mathrm{~cm}$ high), lined with tissue paper and containing artificial diet, under six different regimes (Table 1). Although the control conditions (constant darkness, $24^{\circ} \mathrm{C}, \sim 100$ per cent humidity) were not representative of natural conditions, they are easily repeatable and provide a base-line against which to compare other treatments. High humidity was maintained by dampening the tissue paper with $1 \mathrm{ml}$ of distilled water. For the low humidity treatment, no water was added and ventilation was provided by replacing the solid lids of pots with gauze. For the illuminated treatment, light was provided with two $30 \mathrm{~W}$ fluorescent tubes.

Upon reaching the fourth and fifth instars the colour of larvae was scored (see results). 
Table 1 Rearing regimes used to determine whether the environment influenced larval colour in Mamestra brassicae

Conditions

\begin{tabular}{lccccr}
\hline Treatment & Temperature & Humidity & Light & $\begin{array}{c}\text { Density } \\
\text { (larvae/pot) }\end{array}$ & $\begin{array}{r}\text { Replication } \\
\text { (no. of pots) }\end{array}$ \\
\hline (a) Control & $24^{\circ} \mathrm{C}$ & $\sim 100 \%$ & $24 \mathrm{~h}$ dark & 50 & 10 \\
(b) Light & $24^{\circ} \mathrm{C}$ & $\sim 100 \%$ & $24 \mathrm{~h} \mathrm{light}$ & 50 & 5 \\
(c) Humidity & $24^{\circ} \mathrm{C}$ & Low & 24 h dark & 50 & 5 \\
(d) Temperature & $12^{\circ} \mathrm{C}$ & $\sim 100 \%$ & 24 h dark & 50 & 5 \\
(e) Low density & $24^{\circ} \mathrm{C}$ & $\sim 100 \%$ & 24 h dark & 10 & 10 \\
(f) High density & $24^{\circ} \mathrm{C}$ & $\sim 100 \%$ & 24 h dark & 100 & 5 \\
\hline
\end{tabular}

\section{Larval thermoregulation}

Larval internal temperatures were measured using fine copper-constantan thermocouples and a Comark model 5000 digital thermometer. Thermocouples were inserted approximately $5 \mathrm{~mm}$ into the anus of larvae, aided by gentle squeezing of the body with forceps. This procedure did not apparently adversely affect larvae as most subsequently reached pupation (139 out of 160 larvae). All temperature measurements were made on fifth instar larvae. One larva from each of the four colour categories (see results) was selected at random and a thermocouple inserted in each. Larvae were placed on an horizontal surface of expanded polystyrene to insulate them from the substrate temperature, and held in place with a narrow strip of adhesive tape across the final body segment. They were then left for $15 \mathrm{~min}$ in darkness to equilibrate (in case handling influenced temperature). Simultaneous temperature measurements were then taken from each larva, while a fifth thermocouple was used to record the ambient temperature. Lighting was then supplied with a $60 \mathrm{~W}, 240 \mathrm{~V}$ tungsten bulb (Sylvania). Illumination intensity was controlled by adjusting the distance between larvae and the light source. Larval temperatures were sequentially recorded at each of three increasing lighting intensities, $(40,30$ and $20 \mathrm{~cm}$ from the light source). At each lighting intensity larvae were allowed $15 \mathrm{~min}$ before the temperatures were taken. The thermocouple recording ambient temperature was shaded from direct light. The experiment was replicated using 20 larvae from each colour category at each of two ambient temperatures, $8^{\circ} \mathrm{C}$ and $24^{\circ} \mathrm{C}$, towards the lower and upper end of the temperature range in the field.

\section{Weight, rate of development of larvae, and adult fecundity}

Three hundred and eighty seven freshly moulted fourth instar and 1002 freshly moulted fifth instar larvae were scored for colour and weighed. Two hundred of the newly moulted fifth instar larvae were than placed in individually numbered plastic pots $(4 \mathrm{~cm}$ diameter $\times 3.5 \mathrm{~cm}$ high) containing sufficient artificial diet for them to reach pupation, and stored in the dark at $24^{\circ} \mathrm{C}$. Each was examined daily, and the time to pupation, the sex of the pupae, pupal weight, and duration of the pupal phase recorded.

On hatching adults were randomly paired and housed as above until the female died. The number of fertile eggs laid (assessed by whether they hatched) was recorded.

\section{Statistical analyses}

The genetic component of variation in larval colour $\left(h^{2}\right)$ was estimated by linear regressions of the mean degree of melanization per brood against the midparent value, and against each of the parents in turn (Falconer, 1981), with weighting for brood size. Separate estimates were calculated for colour as fourth and as fifth instars.

Environmental effects on melanization were assessed for each instar using the program Generalised Linear Interactive Modelling (GLIM) (Royal Statistical Society) with binomial errors for the proportions of larvae in each colour category (equivalent to a $\chi^{2}$ test). If the degree of overdispersion was within acceptable limits (when Pearson's $\chi^{2}$ divided by the residual degrees of freedom is $>1$ but $<3$ ), then a dispersion parameter was calculated and used to adjust the scale parameter. A single analysis was carried out comparing all treatments and the controls, followed by a pairwise comparisons between each treatment in turn compared to the controls.

Analysis of variance was used to examine differences between larval temperature excess (body temperature minus ambient temperature) according to larval colour, lighting regime and ambient temperature, with all interactions initially included as factors. Factors which had no significant effect were then 
sequentially removed. Approximation of temperatures to the normal distribution was tested by inspection of residuals. Analysis of variance was also used to test for other morphological and developmental differences between larvae according to melanization: the continuously distributed variables larval and pupal weight, time to pupation, duration of the pupal phase, and also the discretely distributed number of fertile eggs produced, approximated to a normal distribution (confirmed by examination of residuals).

\section{Results}

\section{Variation in melanization}

For the first three larval instars little melanization is apparent, all larvae being pale green. During the moult from third to fourth instars a variable degree of dark pigmentation develops on the dorsal surface, which becomes accentuated in the fifth instar. In order to record this variation a scoring scheme was devised for fourth and fifth instar larvae on a scale of one to four (Fig. 1), similar to that used by Kazimirova (1992). By the sixth instar variation in melanization is reduced, as nearly all larvae develop dark pigmentation on the dorsal surface.

Larvae tend to remain in the same melanization category from fourth to fifth instar when reared under constant conditions (59.4 per cent of larvae) $\left(\chi_{9}^{2}\right.$ test of association $=24.2, P<0.01)$, based on the offspring reared to examine heritability. When changes did occur they took place in either direction, but rarely by more than one category.

\section{Inheritance of larval colour}

Estimates of heritability $\left(h^{2}\right)$ based on regression of brood means against mid-parent values are $0.24 \pm 0.07$ (SD) $(P=0.001)$ and $0.42 \pm 0.10$ (SD) $(P<0.001)$ for fourth and fifth instars, respectively (Fig. 2 ), indicating that variability in the degree of melanization has a genetic component. Estimates were also significant for both instars when brood means were regressed against either parent, and in both instars estimates were higher for the male parent than for the female parent (Table 2).

\section{Environmental effects on larval colour}

Two of the four environmental conditions studied had a significant effect on larval melanization (Table 3 and Fig. 3). Temperature produced the most pronounced effect. In both instars there was a marked reduction in the number of pale larvae (colour one) at $12^{\circ} \mathrm{C}$ compared a)

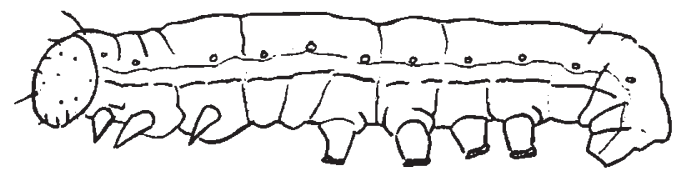

b)

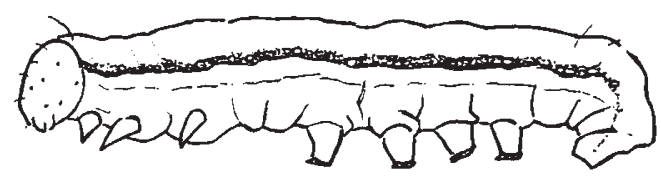

c)



d)

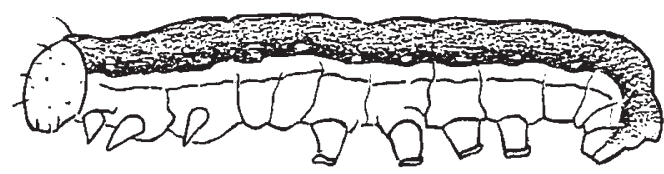

Fig. 1 Classification scheme used to score larval melanization (fourth and fifth instars) of Mamestra brassicae on a scale of one to four. (a) Colour One: larvae entirely lacking melanin. Underside pale cream, lateral line white, dorsal surface pale green. (b) Colour Two: larvae as above but with a darkly pigmented line immediately above the white lateral line, and the darkly pigmented line narrower than the white lateral line. (c) Colour Three: as colour two but the darkly pigmented line broader than the white lateral line, and some melanization across the dorsal surface. (d) Colour Four: as above but full width of the dorsal surface darkly pigmented.

with $24^{\circ} \mathrm{C}$, and a corresponding increase in the proportion of highly melanized larvae (colours three and four). In particular, as fourth instars the proportion of larvae of colour three increased from 7.3 to 52.6 per cent $\left(24^{\circ} \mathrm{C}\right.$ compared to $\left.12^{\circ} \mathrm{C}\right)$.

Rearing larvae at low vs. high humidity produced no effect in fourth instars, but resulted in an increase in the proportion of dark larvae as fifth instars: the frequency of colour four increased from 1.5 to 8.9 per cent. Neither rearing in light vs. dark, nor varying rearing density (for the range of densities used) had an effect on melanization. 


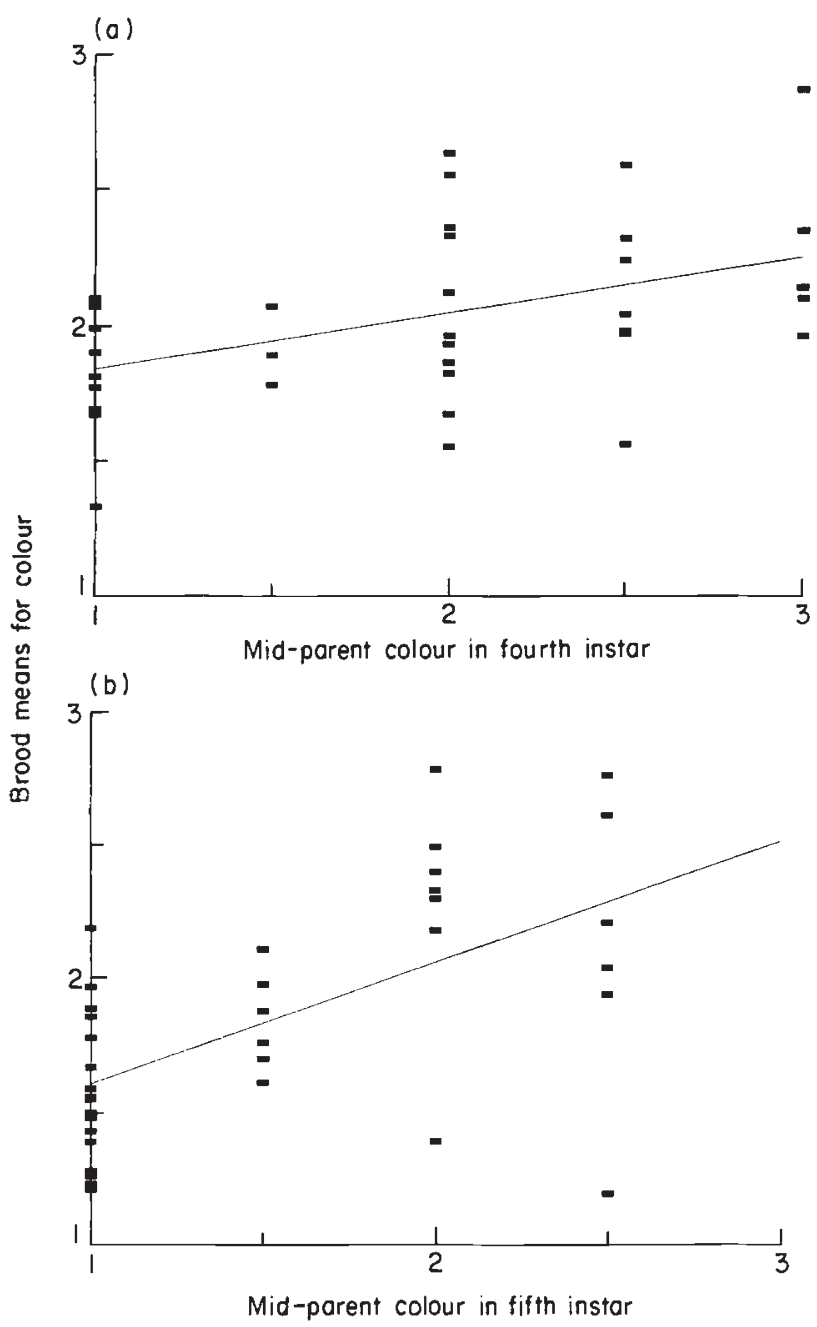

Fig. 2 Estimation of heritability $\left(h^{2}\right)$ of larval colour in Mamestra brassicae from regression of offspring brood means against mid-parental values, with weighting for brood size. (a) Fourth instar. (b) Fifth instar.

Table 2 Heritability estimates $( \pm S D)$ for larval colour in the fourth and fifth instars of Mamestra brassicae, calculated from regressions of broods means against mid-parent values, an against each parent separately

\begin{tabular}{lrrc}
\hline & $F_{1,34}$ & $P$ & $h^{2}$ \\
\hline Fourth instar & & & \\
$\quad$ Mid-parent & 12.8 & 0.001 & $0.24 \pm 0.07$ \\
Female parent & 5.5 & 0.025 & $0.16 \pm 0.07$ \\
$\quad$ Male parent & 12.4 & 0.001 & $0.18 \pm 0.05$ \\
Fifth instar & & & \\
$\quad$ Mid-parent & 16.3 & $<0.001$ & $0.42 \pm 0.10$ \\
Female parent & 6.5 & 0.016 & $0.27 \pm 0.11$ \\
Male parent & 17.6 & $<0.001$ & $0.36 \pm 0.09$ \\
\hline
\end{tabular}

\section{Larval thermoregulation}

In darkness, larval temperature did not differ according to colour $\left(F_{3,156}=2.61, \mathrm{NS}\right)$. When larvae were subjected to a range of lighting intensities, there was a significant lighting-colour interaction $\left(F_{12,620}=19.8\right.$, $P<0.01)$. Relative to the ambient temperature, the body temperature of dark larvae increased more in response to increasing light intensity than did that of pale larvae (Fig. 4). At the highest light intensity the temperature of dark larvae (colour four) was on average $3.5^{\circ} \mathrm{C}( \pm 0.15 \mathrm{SE})$ above ambient, compared to $1.25^{\circ} \mathrm{C}( \pm 0.28 \mathrm{SE})$ for pale larvae (colour one). This difference was consistent: in all 40 observations at the highest light intensity, the temperature of dark larvae was greater than that of pale larvae. Temperature differences between larvae according to pigmentation were not affected by the ambient temperature $\left(F_{3,620}=2.46, \mathrm{NS}\right)$.

\section{Variation in weight, development rate and fecundity}

The weight of newly moulted ( \pm 12 hrs) fourth instar larvae differed according to their degree of melanization in the order colour one $>$ colour two $>$ colour three $>$ colour four, dark larvae tending to be lighter in weight $\left(F_{3,383}=21.06, P<0.01\right)$ (Fig. 5). Larval weight also differed according to melanization as fifth instars, although the trend was less clear, larvae differing in weight in the order colour one $>$ colour three $>$ colour two $>$ colour four $\left(F_{3,998}=3.09, P<0.05\right)$ (Fig. 5).

Differences in larval weight were lost by the time of pupation, so that pupal weights did not differ according to the colour of the larvae as a fifth instar $\left(F_{3,175}=0.105\right)$. There were no differences in the time taken to reach pupation $\left(F_{3,175}=0.236\right)$ or in the duration of the pupal phase $\left(F_{3,175}=0.175\right)$. No differences were found in the frequency distribution of melanization categories between the sexes $\left(\chi_{3}^{2}=0.95\right)$. Fecundity varied greatly between pairs of adults, some producing no eggs (presumably because they did not mate) and others producing a maximum of 942 fertile eggs. Fecundity was not significantly related to larval melanization of either of the parents $\left(F_{3,68}=0.36\right.$, NS and 1.07, NS for males and females respectively), although the great individual variation may have obscured any existing trends.

\section{Discussion}

Variation in melanization of fourth and fifth instar larvae of $M$. brassicae has a genetic basis, which can be mediated to a large degree by the environment in which the larvae are reared prior to these instars, particularly with regard to temperature. Although these results 
Table 3 Differences in larval colour morph frequencies following rearing of Mamestra brassicae under differing environmental regimes

\begin{tabular}{|c|c|c|c|c|c|c|}
\hline & \multicolumn{3}{|c|}{ Instar 4} & \multicolumn{3}{|c|}{ Instar 5} \\
\hline & $\chi^{2}$ & d.f. & Significance & $\chi^{2}$ & d.f. & Significance \\
\hline All treatments & 17.7 & 20 & NS & 8.0 & 20 & NS \\
\hline Light & 4.7 & 4 & NS & 3.0 & 4 & NS \\
\hline Humidity & 1.2 & 4 & NS & 9.5 & 4 & $*$ \\
\hline Temperature & 58.4 & 4 & $* * *$ & 24.7 & 4 & $* * *$ \\
\hline Density & 4.8 & 8 & NS & 1.7 & 8 & NS \\
\hline
\end{tabular}

Tests were carried out using GLIM with binomial errors, firstly on all treatments, and then on specific environmental factors, using pairwise comparison with controls.

$* P \leqslant 0.05, * * * P \leqslant 0.001$.
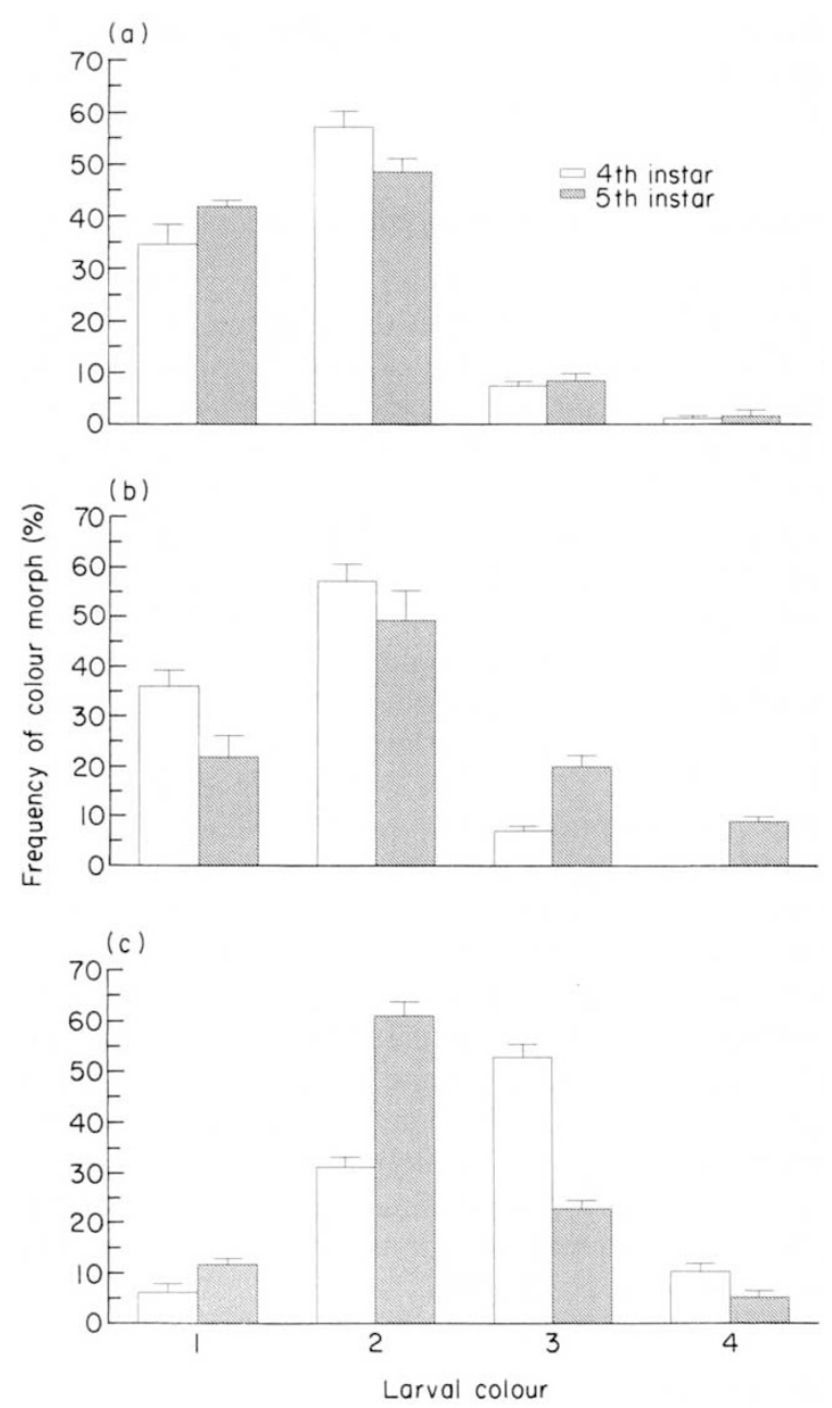

Fig. 3 Colour morph frequencies of fourth and fifth instar larvae of Mamestra brassicae after rearing under three differing environmental regimes (details in text). Figures given are means for 10 replicates of 50 larvae (a) or 5 replicates of 50 larvae (b-c), $\pm \mathrm{SE}$. (a) $24^{\circ} \mathrm{C}, 100$ per cent humidity. (b) $24^{\circ} \mathrm{C}$, low humidity. (c) $12^{\circ} \mathrm{C}, 100$ per cent humidity.

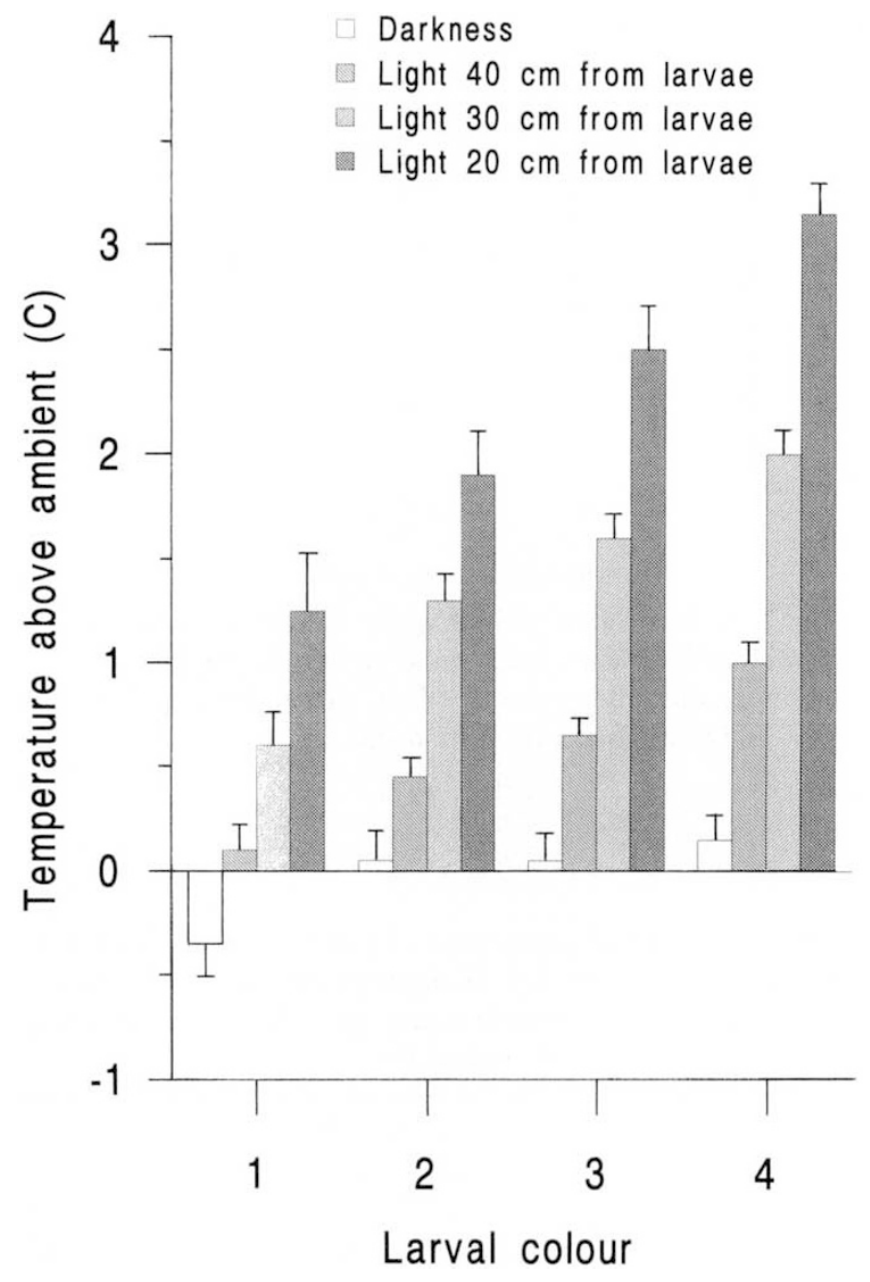

Fig. 4 Larval temperature excess ( $\pm S E$ ), comparing colour morphs of Mamestra brassicae under four illumination regimes. Figures are for 40 observations, combining 20 at each of two ambient temperatures, $8^{\circ} \mathrm{C}$ and $24^{\circ} \mathrm{C}$ (ambient temperature had no significant effect on the temperature excess of larvae). Lighting was provided by a $60 \mathrm{~W}$ tungsten bulb. 




Fig. 5 Mean larval weights ( $\pm \mathrm{SE}$ ) of Mamestra brassicae in each colour class.

were obtained on artificial diet, which may itself have an effect on the frequency of colour morphs, I suggest that the direction of the observed frequency shifts in response to temperature and humidity are unlikely to change according to diet. Both the genetic variability and phenotypic plasticity may be explained, at least in part, by thermoregulatory selection pressures. Dark larvae absorb radiated heat more efficiently, and so maintain a higher body temperature, than do pale larvae. Under equal conditions dark phase larvae exhibit greater activity, respiration rate, growth rate, consume more food, and contain a higher concentration of lactic acid than pale larvae (Matthée, 1945; Iwao, 1963; Shibazaki \& Ito, 1969; Hodjat, 1970; Fescemyer \& Hammond, 1986). Thus one might expect dark larvae to be favoured at high latitudes and altitudes, and during spring and autumn in temperate climates ( $M$. brassicae larvae are not found in winter). In some adult Lepidoptera increased melanization is found in populations living at high altitude or latitudes, and is thought to allow activity at lower ambient temperatures than can be achieved by individuals lacking melanization (Hovanitz, 1948; Watt, 1968; Dennis and Shreeve, 1989). In larvae of the moth, Ctenucha virginica (Arctiidae), spring and autumn larvae are darker than summer larvae, which Fields \& McNeil (1988) suggest is an adaptive response to aid thermoregulation. The increased melanization of larvae reared at low temperatures reported here supports this contention, and suggests that larval melanin production may respond adaptively to environmental factors.

If melanization is advantageous under some conditions, it is necessary to propose opposing selectinn to maintain genetic variability. Two possibilities seem most likely: during hot weather and strong sunlight it is reasonable to predict that dark larvae may be subject to heat stress. Alternatively or additionally, dark larvae may be more apparent to predators (they are more apparent to the human eye when reared on cabbage plants; pers. obs.). Genetic variation within populations may be maintained by fluctuating weather conditions altering the selective value of phenotypes. Both thermoregulatory and predation pressures will be mediated by larval behaviour, particularly with regard to the time of day at which they are active, and the positions adopted on the host plant. Although no detailed study has been carried out of the behaviour of $M$. brassicae larvae in this respect, larvae do remain on the host plant, and are active, during the day (pers. obs.), and so are exposed to sunlight and predators.

The association between melanization and weight is puzzling, for these larvae were reared in darkness. An effect of melanization on body temperature and hence on metabolic rate could result in size differences according to colour, were larvae subject to radiant energy, but in the dark body temperatures did not differ significantly according to colour. Correlations between larval size and colour have been described in other noctuid moths (Long, 1953; Iwao, 1962), suggesting that it may be a general phenomenon. The lack of any corresponding differences in pupal weight, or in time taken to reach pupation, suggests that dark larvae, which on average weigh less in the fifth instar, grow more rapidly during fifth and sixth instars so that they catch up the weight difference before pupation.

Surprisingly, rearing density produced no response in terms of melanization in either fourth or fifth instars: previous studies suggest that darker larvae become more common in fourth, fifth and sixth instars when reared at high densities (Hirata, 1962; Kazimirova, 1992). This discrepancy may be due to genetic differences between the stocks used, or alternatively it could be attributed to interactions between environmental factors: for example Kazimirova (1992) carried out density experiments at 65 per cent humidity and with a 
16:8 (L:D) photoperiod, which may produce results different from those under the conditions used here. Kazimirova also used slightly lower densities of larvae (range 14.7-117.8 $\mathrm{cm}^{3}$ /larva, compared to 20.8-166.5 $\mathrm{cm}^{3} /$ larva in this study). Most previous studies which describe a density effect on melanization compared solitary larvae with those reared at high density (for example, Matthée, 1945, 1947; Long, 1953). Perhaps inclusion of a solitary treatment in this study may have revealed a relationship between larval colour and density.

Larval colour variation in $M$. brassicae provides an excellent subject for evolutionary studies: it has a genetic basis, and is likely to be subject to selection via a direct effect on larval temperature (it may also influence apparency to predators, although this was not tested in this study). Additionally, it exhibits developmental plasticity which appears to be adaptive. Only detailed studies of larval behaviour and survival under natural conditions, and of genetic variation within and between wild populations, can reveal whether this striking example of natural variability is, as I suggest, maintained by selection pressures operating through thermoregulation and predation.

\section{Acknowledgements}

I would like to thank Drs J.S. Cory, T. Williams and an anonymous referee for comments on an earlier draft, R.S. Hails for statistical advice, and T. Carty for invaluable assistance in insect rearing.

\section{References}

BRAKEFIELD, P. M. 1984. The ecological genetics of quantitative characters in Maniola jurtina and other butterflies. In: Vane-Wright, R.I. and Ackery P.R. (eds) The Biology of Butterflies. Symposium of the Royal Entomological Society, vol. 11, pp. 167-190. Academic Press, London.

BUROV, V. AND MOKROUSOVA, E. P. 1970. On the regulating role of the population density of insects after the example of Barathra brassicae L. (Lepidoptera, Noctuidae). Entomol. Obozr., 49, 257-263.

DENNIS, R. L. H. AND SHREEVE, T. G. 1989. Butterfly wing morphology variation in the British Isles: the influence of climate, behavioural posture and the hostplant-habitat. Biol. J. Linn. Soc., 38, 323-348.

Dowdeswell, w. H. 1981. The Life of the Meadow Brown. Heinemann Educational Books, London.

DRooz, A. T. 1966. Color studies of reared elm spanworm larvae and pupae. Ann. Entomol. Soc. Am., 59, 568-573.

FALCONER, D. S. 1981. Introduction to Quantitative Genetics, 2 edn. Longman, London.

FAURE, J. C. 1943a. Phase variation in the armyworm, Laphygma exempta (Walk.). Sci. Bull. Dep. Agric. Forest S. Africa, 234, 2-17.
FAURE, J. C. 1943b. The phases of the lesser armyworm (Laphygma exigua (Hübn.)). Fmg in S. Afr., 18, 69-78.

FESCEMYER, H. W. AND HAMMOND, A. M. 1986. Effect of density and plant age on color phase variation and larval development of velvetbean caterpillar, Anticarsia gemmatalis Hübner (Lepidoptera: Noctuidae). Envir. Entomol., 15, 784-789.

FIELDS, P. G. AND McNEIL, J. N. 1988. The importance of seasonal variation in hair coloration for thermoregulation of Ctenucha virginica larvae (Lepidoptera: Arctiidae). Physiol. Zool., 13, 165-175.

HINTZE-PODUFAL, C. 1974. Untersuchungen zur Farbmusterbildung bei den Larven von Eudia pavonia L. (Lepidoptera: Saturniidae). Biol. Zbl., 93, 545-559.

HIRATA, S. 1954. The phase variation observed in the armyworm, Barathra brassicae L. I. The relation between the rearing density and the variation of body colour of sixth-instar larva, weight of pupa, and rate of diapause. Oyo-Dobats. Zasshi., 19, 41-46.

HIRATA, s. 1957a. The phase variation observed in the armyworm, Barathra brassicae L. III. Influence of larval density on body color of the fourth and fifth instar larva. Bull. Educ. Fac. Hirosaki Univ., 3, 50-56.

HIRATA, s. $1957 \mathrm{~b}$. The phase variation observed in the armyworm, Barathra brassicae L. IV. Some regulating mechanisms of development in crowded population. Jap. J. Appl. Entomol. Zool., 1, 204-208.

HIRATA, S. 1962. On the phase variation of cabbage armyworm, Mamestra (Barathra) brassicae (L.). VI. Phase variation in larval characters under different conditions of density and temperature. Jap. J. Ecol., 12, 223-228.

HODJAT, s. H. 1970. Effects of crowding on colour, size and larval activity of Spodoptera littoralis (Lepidoptera: Noctuidae). Entomologia exp. appl., 13, 97-106.

HOVANITZ, w. 1948. Differences in the field activity of two female color phases of Colias butterflies at various times of the day. Contrib. Lab. Vert. Biol., 41, 1-37.

HUNTER, F. R., CROOK, N. E. AND ENTWISTLE, P. F. 1984. Viruses as pathogens for the control of insects. In: Grainger, J.M. and Lynch, J.M. (eds) Microbiological Methods for Environmental Biotechnology, pp. 323-347. Academic Press, London.

IWAO, S. 1962. Studies on the phase variation and related phenomena in some lepidopterous insects. Mem. Coll. Agric. Kyoto Univ., 84, 1-80.

IWAO, S. 1963. Some behavioural changes associated with phase variation in the armyworm, Leucania separata Walker. 1. Reaction of larvae to mechanical stimuli. Jap. J. Appl. Entomol. Zool., 7, 125-131.

JOHNSON, S. J., FOIL, L. D., HAMMOND, A. M., SPARKS, T. C. AND CHURCH, G. E. 1985. Effects of environmental factors on phase variation in larval cotton leafworm, Alabama argillacea (Lepidoptera: Noctuidae). Ann. Entomol. Soc. Am., 78, 35-41.

JONES, J. S., LEITH, B. H. AND RAWLINGS, P. 1977. Polymorphism in Cepaea: a problem with too many solutions? Ann. Rev. Ecol. Syst., 8, 109-43.

JONES, D. A. 1989.50 years of studying the scarlet tiger moth. Trends Ecol. Evol., 4, 298-301. 
KAzIMIRoVA, M. 1992. The role of physical contact in the induction of phase polymorphism of Mamestra brassicae (Lepidoptera: Noctuidae). Acta Entomologica Bohemoslovaca, 89, 87-95.

ketTlewell, B. 1973. The Evolution of Melanism. Clarendon Press, Oxford.

KUNIM1, Y. AND YAMADA, E. 1990. Relationship of larval phase and susceptibility of the armyworm, Pseudaletia separata Walker (Lepidoptera: Noctuidae) to a nuclear polyhedrosis virus and a granulosis virus. Appl. Ent. Zool., 25, 289-297.

LONG, D. B. 1953. Effects of population density on larvae of Lepidoptera. Trans. R. Ent. Soc. Lond., 104, 543-585.

MATTHÉ, J. J. 1945. Biochemical differences between the solitary and gregarious phases of locusts and noctuids. Bull. ent. Res., 36, 343-371.

MATThEE, J. J. 1947. Phase variation in the lawn caterpillar (Spodoptera abyssinia Guen.). J. ent. Soc, S. Afr., 10, 16-23.

PORTER, K. 1983. Multivoltinism in Apanteles bignellii and the influence of weather on synchronization with its host Euphydryas aurinia. Entomologia exp. appl., 34, 155-162. SAPPINGTON, T. W., SAPPINGTON, W. AND SHOWERS, W. B. 1992. Lack of translation of density-induced morphological polyphenism to long-duration flight behaviour of black cutworm (Lepidoptera: Noctuidae). Ann. Entomol. Soc. Am., 85, 188-194.
SASAKAWA, M. AND YAMAZAKI, s. 1967. Effect of population density on the larval coloration and development of larva and pupa in the larger pellucid hawk moth, Cephonodes hylas L. (Lepidoptera: Sphingidae). Jap. J. Appl. Entomol. Zool., 11, 157-163.

SAULICH, A. C. 1975. The group effect in the photoperiodic induction of diapause in the cabbage moth Barathra brassicae. Zool. Zh., 54, 1335-1339.

SHIBAZAKI, A. AND ITO, Y. 1969. Respiratory rates of green and black larvae of the armyworm, Leucania separata (Lepidoptera: Noctuidae). Appl. Ent. Zool., 4, 100-101.

SMITH, D. A. S., Shoesmith, E. A. AND SMITH, A. G. 1988. Pupal polymorphism in the butterfly Danaus chrysippus (L.) environmental, seasonal and genetic influences. Biol. $J$. Linn. Soc., 33, 17-50.

ToJo, s. 1991. Variation in phase polymorphism in the common cutworm, Spodoptera litura (Lepidoptera: Noctuidae). Appl. Entomol. Zool., 26, 571-578.

WATT, W. B. 1968. Adaptive significance of pigment polymorphisms in Colias butterflies I. Variation in melanin pigment in relation to thermoregulation. Evolution, 22, 437-458

WICKMAN, P. O. AND KARLSSON, B. 1987. Changes in egg colour, egg weight and oviposition rate with the number of eggs laid by wild females of the small heath butterfly, Coenonympha pamphilus. Ecol. Ent., 12, 109-114. 